\title{
DETEKSI SEBARAN MUATAN PADATAN TERSUSPENSI DENGAN MODEL EMPIRIS DAN MODEL SEMI-ANALITIK DI PERAIRAN BEKASI
}

\section{DETECTION OF TOTAL SUSPENDED SOLIDS DISTRIBUTION USING EMPIRICAL AND SEMI-ANALYTICAL MODELS IN BEKASI}

\author{
Pingkan Mayestika Afgatiani*, Maryani Hartuti, \& Syarif Budhiman \\ Pusat Pemanfaatan Penginderaan Jauh, LAPAN, Jakarta 13170, Indonesia \\ *E-mail: pingkan.mayestika@lapan.go.id
}

\begin{abstract}
One of the parameters in water quality is total suspended solids (TSS). TSS consists of mud and microorganisms caused by erosion of soil flowed into water bodies. This study aimed to detect suspended sediments in Bekasi coastal water by comparing empirical and semi-analytic models. Landsat 8 was used for analysis of suspended solids using the Google Earth Engine platform. The workflow of this study consisted of land masking by area delineation using surface reflectance image data, TSS analysis, and visualization. Then validation was done with in situ data, model selection and time series implementation. TSS detection results were displayed with a different color display according to the concentration. Validation test results with in situ data showed that the value of the Semi-Analytical Absolute Error (NMAE) model was closer to the minimum requirement of $66.8 \%$, far different from the empirical model of 43768\%. The value of Root Mean Square Error (RMSE) also showed that the semi-analytic model produced a much smaller value of 51.4 and the empirical model of 58577.2. This showed that the semi-analytic model has a better value in detecting the distribution of TSS. Time series analysis showed that the distribution of MPT in 2015-2019 in coastal waters had a very high TSS distribution, due to the number of ponds and river estuaries. Therefore, semi-analytical model was more recommended for estimating TSS concentrations than empirical model.
\end{abstract}

Keywords: Bekasi, Google Earth Engine, Landsat 8, TSS, water quality

\begin{abstract}
ABSTRAK
Salah satu parameter dalam kualitas air adalah muatan padatan tersuspensi (MPT). Muatan padatan tersuspensi terdiri dari lumpur, pasir dan jasad renik yang disebabkan pengikisan tanah yang terbawa ke badan air. Penelitian ini bertujuan untuk mendeteksi sedimen tersuspensi di perairan Bekasi. Landsat 8 digunakan untuk analisis padatan tersuspensi dengan platform Google Earth Engine dengan membandingkan antara model empiris dan semi-analitik. Alur studi ini meliputi deliniasi wilayah non air menggunakan data citra surface reflectance, analisis MPT, dan visualisasi. Selanjutnya dilakukan validasi dengan data in situ, pemilihan model dan implementasi time series. Hasil deteksi MPT tertampil dengan tampilan warna yang berbeda sesuai dengan konsentrasinya. Hasil uji validasi dengan data in situ menunjukkan nilai Normalized Mean Absolute Error (NMAE) model semi-analitik lebih mendekati syarat minimum yaitu sebesar $66,8 \%$, berbeda jauh dengan model empiris sebesar 43768\%. Nilai Root Mean Square Error (RMSE) juga terlihat bahwa model semi-analitik menghasilkan nilai yang jauh lebih kecil sebesar 51,4 dan model empiris sebesar 58577,2. Hal ini menunjukkan bahwa model semi-analitik memiliki nilai yang lebih baik dalam mendeteksi sebaran MPT. Analisis time series menunjukkan bahwa persebaran MPT tahun 2015-2019 di perairan pesisir memiliki sebaran MPT yang sangat tinggi, karena banyaknya tambak dan muara sungai. Oleh karena itu, model semi-analitik lebih direkomendasikan untuk mengestimasi konsentrasi MPT dibandingkan dengan model empiris.
\end{abstract}

Kata Kunci: Bekasi, Google Earth Engine, Landsat 8, MPT, kualitas air 


\section{PENDAHULUAN}

Wilayah pesisir merupakan wilayah yang produktif. Banyak kegiatan yang dapat dilakukan di wilayah ini seperti tambak, pemukiman, wisata bahari, hingga transportasi air. Tentu kegiatan tersebut dapat memengaruhi kualitas perairan. Kepmen KLH No. 51 tahun 2004 menyebutkan parameter fisika dari kualitas perairan laut yakni muatan padatan tersuspensi (MPT), kekeruhan, dan kecerahan. Jika hendak mengetahui kualitas air dari suatu perairan, kajian yang umum dilakukan adalah pengambilan sebanyak mungkin sampel air secara in situ kemudian dilanjutkan dengan analisis di laboratorium. Hal ini tentunya akan membutuhkan waktu dan biaya yang lebih banyak. Salah satu metode yang dapat dilakukan untuk mengatasi hal tersebut yakni dengan teknologi pengindraan jauh. Beberapa parameter fisika seperti padatan tersuspensi total dapat diketahui dengan menggunakan sensor pengindraan jauh.

Kemampuan sensor pengindraan jauh untuk dapat mendeteksi objek menggunakan pantulan spektral inilah yang menarik untuk dikaji. Pengkajian citra pengindraan jauh dalam analisis MPT telah dilakukan sejak lama. Umumnya, penelitian yang sudah ada banyak menggunakan citra Landsat sebagai bahan utama dalam analisis dan dipadukan dengan model yang telah dibangun sebelumnya seperti pada penelitian Indeswari et al. (2018); Sholihah et al. (2016); Arief et al. (2017); dan Parwati \& Purwanto (2017).

Banyak model yang dibangun untuk menentukan kandungan MPT pada suatu perairan. Kong et al. (2015) menjelaskan terdapat 3 jenis model yang biasa digunakan dalam menganalisis MPT yakni model empiris, teoritis, dan semi-analitik. Model empiris merupakan metode paling sederhana. Umumnya, model empiris yang dibangun antara satu daerah dengan daerah yang lain dapat berbeda untuk menganalisis hal yang sama. Model empiris dapat digunakan dalam menentukan nilai awal proses analitik untuk meningkatkan proses dengan mempersempit kisaran variasi (Ligi et al., 2017). Model teoritis didasarkan pada teori transfer radiasi untuk simulasi spektrum pada Top of Atmosphere (TOA) dengan perbedaan MPT dan kondisi atmosfer (Kong et al., 2015). Model semi-analitik untuk analisis MPT menggunakan Inherent Optical Properties (IOP) regional in situ. Spesifik IOP yang digunakan sebagai parameter model tersebut berpotensi menghasilkan nilai MPT yang terbaik (Dorji et al., 2016). Penelitian ini bertujuan untuk mendeteksi sebaran MPT menggunakan citra satelit Landsat 8 dengan 2 model, yakni empiris dan semi-analitik.

\section{METODE PENELITIAN}

\subsection{Lokasi Penelitian}

Penelitian ini dilakukan di perairan pantai utara Kabupaten Bekasi, Jawa Barat (Figure 1). Titik-titik sampling (in situ) dipilih mulai dari yang terdekat dengan muara sampai perairan yang jernih. Lokasi ini terdapat aktivitas perikanan berupa kegiatan tambak, wisata mangrove, dan kegiatan penangkapan ikan.

\subsection{Penyiapan Citra}

Salah satu cara penyiapan citra yang saat ini sedang populer dikalangan peneliti pengindraan jauh adalah melakukan analisis data citra menggunakan Google Earth Engine (GEE). Secara umum, langkahlangkah yang dilakukan yakni dengan data reflektansi permukaan (surface reflectance data), mendeliniasi wilayah air dan non air, dan menggunakan model untuk mengetahui nilai MPT. Secara lengkap yakni data yang digunakan merupakan data Landsat 8 surface reflectance dari GEE. Set data ini merupakan pantulan permukaan yang telah dikoreksi secara atmosferik dari sensor Landsat 8 OLI/TIRS.

Citra ini mengandung 5 band Visible and Near-Infrared (VNIR) dan 1 band ShortWave Infrared (SWIR) untuk ortorektifikasi surface reflectance dan 2 band Thermal 


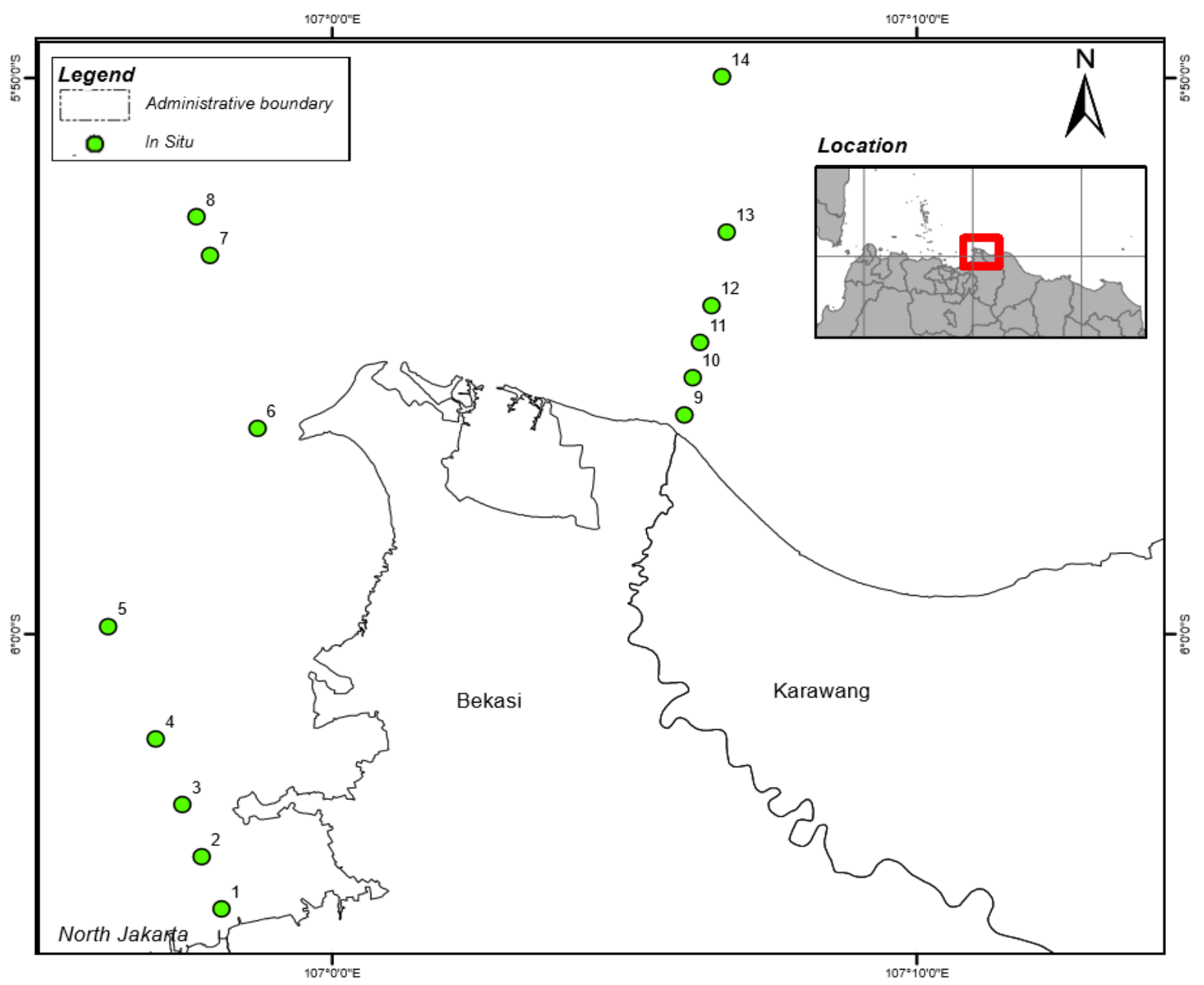

Figure 1. Study area in Bekasi coastal waters.

Infrared (TIR) untuk ortorektifikasi suhu dan kecerahan. Selanjutnya, analisis Normalized Difference Water Index (NDWI) dilakukan untuk mendeliniasi wilayah air dan bukan air. Hal ini dilakukan untuk mempermudah dalam tahapan analisis MPT. Pada tahapan ini digunakan fungsi untuk mengatur opacity masing-masing piksel berdasarkan piksel dalam citra bernilai bukan nol. Piksel yang bernilai 0 pada masking akan dikeluarkan dari perhitungan. Selanjutnya, mengubah gambar menjadi RGB 8-bit untuk display. Analisis MPT dengan menggunakan 2 model yakni model semi-analitik yang telah dibangun oleh Budhiman (2004) dan model empiris yang dibangun oleh Adawiah (2018). Model semi-analitik (2004) dibangun di Delta Mahakam dan empiris (2018) dibangun di perairan Bekasi. Kedua model ini telah diverifikasi dengan data lapangan. Model semi-analitik diketahui memiliki nilai $\mathrm{R}^{2}$ sebesar 0,94, sedangkan model empirik (2018) memiliki nilai $\mathrm{R}^{2}$ sebesar 0,824 dengan data lapangannya.

Model Budhiman et al. (2004) sebagai berikut:

$$
\begin{aligned}
& \operatorname{MPT}\left(\frac{m g}{L}\right)= \\
& 8.1429\left(\exp \left(2^{23.704 x \text { Kananmerah }}\right)\right)
\end{aligned}
$$

Model Adawiah et al. (2018) sebagai berikut:

$$
\begin{aligned}
& \operatorname{MPT}\left(\frac{m g}{L}\right)=155.28 \mathrm{X}^{3}-2740.4 \mathrm{X}^{2}+ \\
& 15912 \mathrm{X}-30261
\end{aligned}
$$


$\mathrm{X}=\frac{\text { Kanal Merah }}{(\text { Kanal Hijau })(\text { Kanal Hijau })}$

Setelah dilakukan analisis MPT, visualisasi hasil dari analisis dengan memberikan pemberian warna. Hal ini dilakukan agar dapat lebih mudah dalam memahami persebaran MPT.

\subsection{Pengukuran MPT In situ}

Pengukuran nilai MPT in situ dengan menggunakan metode Baird et al. (2017) untuk mengetahui kandungan MPT yang sebenarnya pada perairan Bekasi.

\subsection{Uji Validasi}

Hasil pengolahan citra divalidasi dengan data in situ menggunakan Normalized Mean Absolute Error (NMAE). Syarat minimum NMAE sebesar $\leq 30 \%$.

$$
\begin{aligned}
& \operatorname{NMAE}(\%)=\frac{1}{N} \sum\left|\frac{X \text { estimasi }-X \text { observasi }}{X \text { observasi }}\right| \\
& \text { x100 }
\end{aligned}
$$

Keterangan: X estimasi merupakan nilai hasil pengolahan citra dan $\mathrm{X}$ observasi merupakan nilai hasil pengukuran lapangan, serta $\mathrm{N}$ merupakan jumlah sampel.

Selain menggunakan NMAE, digunakan pula Root Mean Square Error (RMSE) dengan rumus:

$$
\mathrm{RMSE}=\sqrt{\frac{\sum(X \text { observasi }-X \text { estimasi })^{2}}{N}}
$$

\subsection{Analisis Time Series}

Analisis deret berkala (time series) dengan memanfaatkan data citra Landsat 8 selama 5 tahun sebelumnya (Table 1). Data

Table 1. Acquisition time.

\begin{tabular}{cc}
\hline Years & Acquitition Time \\
\hline 2015 & August \\
2016 & August \\
2017 & July \\
2018 & July \\
2019 & August \\
\hline
\end{tabular}

yang digunakan merupakan data mosaik dalam 1 bulan tersebut untuk mendapatkan citra yang sedikit awan.

\section{HASIL DAN PEMBAHASAN}

\subsection{Hasil}

Sebaran MPT terlihat berdasarkan warna yang berbeda sesuai dengan konsentrasinya (Figure 2). Hasil konsentrasi MPT yang sangat rendah dipresentasikan dengan warna biru muda, sedangkan konsentrasi rendah berwarna biru, konsentrasi sedang berwarna hijau, konsentrasi tinggi berwarna kuning, dan konsentrasi sangat tinggi berwarna merah.

Uji validasi dengan menggunakan koefisien determinasi $\left(\mathrm{R}^{2}\right)$, korelasi, NMAE, dan RMSE dengan hasil pada Table 2. Model semi-analitik memiliki nilai yang lebih baik daripada model empiris. Uji ini bertujuan untuk melihat kedekatan hubungan dari data in situ dengan model yang telah dibangun. Semakin dekat maka model tersebut semakin baik untuk digunakan.

Penerapan model semi-analitik pada time series terlihat pada Figure 3. Sebaran MPT yang terlihat berubah pada tiap tahun. Namun, untuk area pesisir terlihat memiliki persebaran konsentrasi MPT yang cenderung tinggi. Table 3 menjelaskan konsentrasi MPT pada tiap titik. Lokasi setiap titik pengambilan sampel dapat dilihat pada Figure 1 . Kelas No Data pada perairan berarti tidak terdapat data karena tertutup oleh awan.

\subsection{Pembahasan}

Persebaran MPT ditampilkan berdasarkan konsentrasi yang diwakilkan dengan berbagai warna. Dapat terlihat persebaran MPT di perairan Bekasi terlihat pada Figure 2. Pembagian rentang nilai konsentrasi dilakukan untuk memudahkan dalam memahami tingkat konsentrasi MPT yang terdeteksi. Seluruh data yang digunakan dalam menghasilkan nilai sebaran MPT menggunakan data dan area yang sama, hanya pendekatannya dilakukan dengan 2 


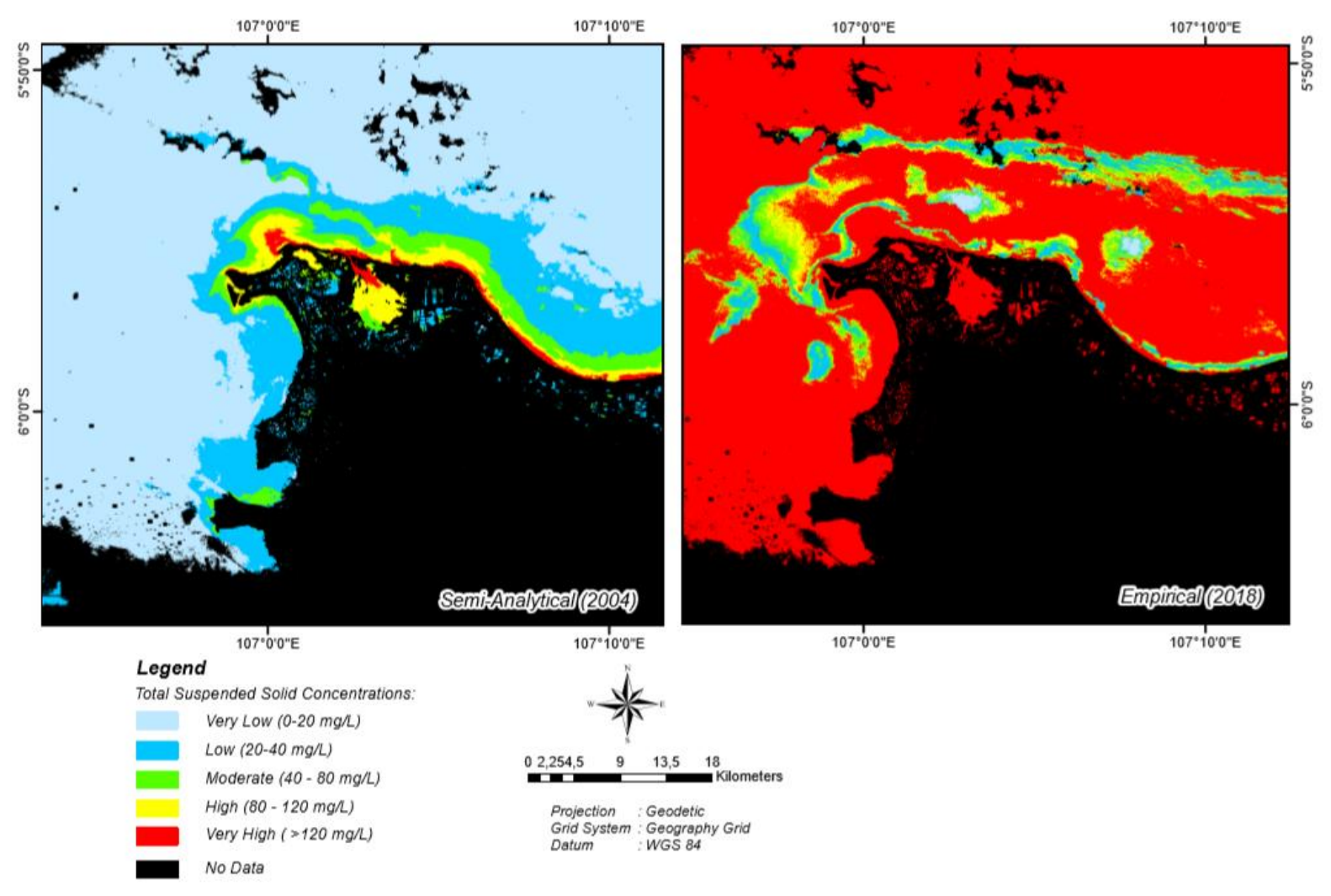

Figure 2. Distribution of TSS in August 2019 with Semi-Analytic Model (2004) and Empirical Model (2018). The color scale applied to both maps.

Table 2. Image processing validation test with Empirical Model (2018) on August, 6-10 th 2018, Semi-Analytic (2004) on July, 3-5 2003 and in situ data on August, 23-25 th 2019.

\begin{tabular}{|c|c|c|c|c|c|c|c|c|c|c|c|}
\hline \multirow[b]{2}{*}{ Point } & \multirow[b]{2}{*}{$\begin{array}{c}\text { In } \\
\text { situ } \\
(m g / \\
L)\end{array}$} & \multicolumn{4}{|c|}{ Empirical } & \multicolumn{6}{|c|}{ Semi-Analytical } \\
\hline & & $\begin{array}{c}T S S \\
(m g / \\
L)\end{array}$ & $R^{2}$ & $\begin{array}{c}\text { Cor } \\
\text { rel } \\
\text { atio } \\
n\end{array}$ & $\begin{array}{c}N M A \\
E \\
(\%)\end{array}$ & $\begin{array}{c}R M \\
S E\end{array}$ & $\begin{array}{c}T S S \\
(m g / L \\
)\end{array}$ & $R^{2}$ & $\begin{array}{c}\text { Cor } \\
\text { rel } \\
\text { atio } \\
n\end{array}$ & $\begin{array}{c}N M A \\
E \\
(\%)\end{array}$ & $\begin{array}{c}R M \\
S E\end{array}$ \\
\hline 1 & 80.7 & 639.9 & & & & & 70.9 & & & & \\
\hline 2 & 36.0 & 9100.8 & & & & & 12.9 & & & & \\
\hline 3 & 63.3 & 14365.8 & & & & & 12.5 & & & & \\
\hline 5 & 52.0 & 186278.6 & & & & & 15.7 & & & & \\
\hline 6 & 80.3 & 82573.7 & & & & & 18.6 & & & & \\
\hline 7 & 67.0 & 18999.3 & & & & & 17.4 & & & & \\
\hline 8 & 93.0 & 47731.5 & 0.1 & -0.3 & 43768 & 58577. & 16.1 & 0. & 0.6 & 59.6 & 51.4 \\
\hline 9 & 71.0 & 38.5 & & & & & 12.2 & & & & \\
\hline 10 & 61.0 & 14426.4 & & & & & 11.7 & & & & \\
\hline 11 & 101.3 & 209.4 & & & & & 19.7 & & & & \\
\hline 12 & 79.3 & 193.1 & & & & & 25.3 & & & & \\
\hline 13 & 77.7 & 95.8 & & & & & 58.2 & & & & \\
\hline 14 & 113.0 & 140.1 & & & & & 155.8 & & & & \\
\hline
\end{tabular}

Note: The value of R2, correlation, and NMAE are the result of the calculation of all points. 


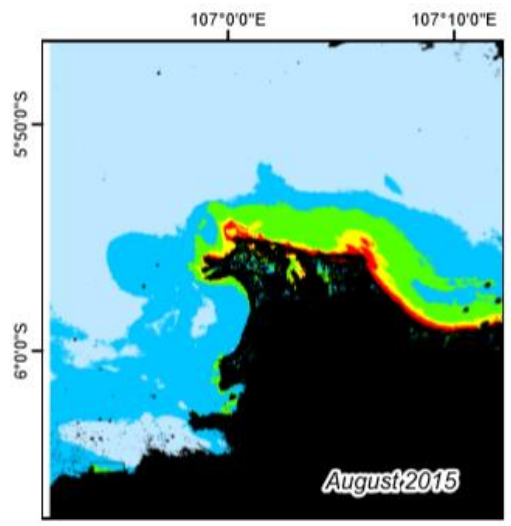

(a)

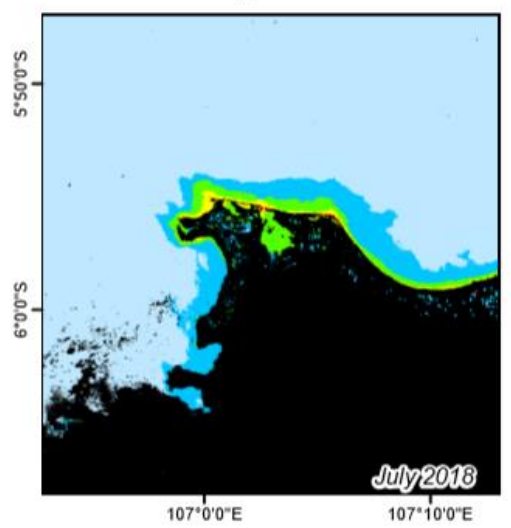

(d)

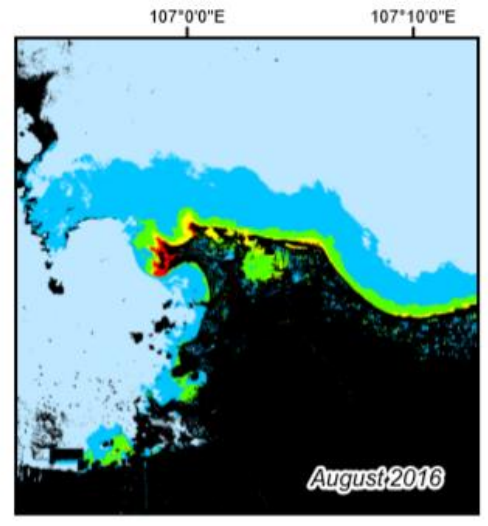

(b)

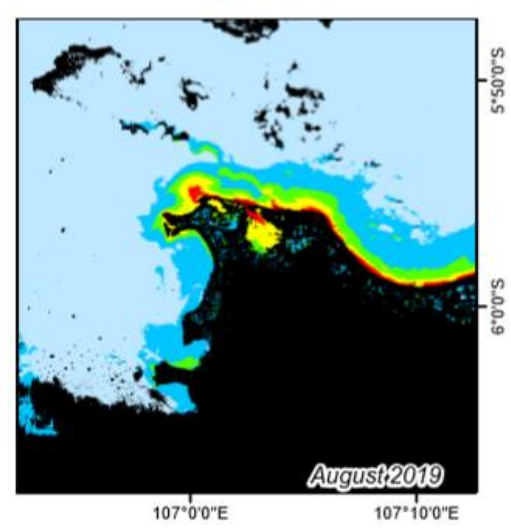

(e)

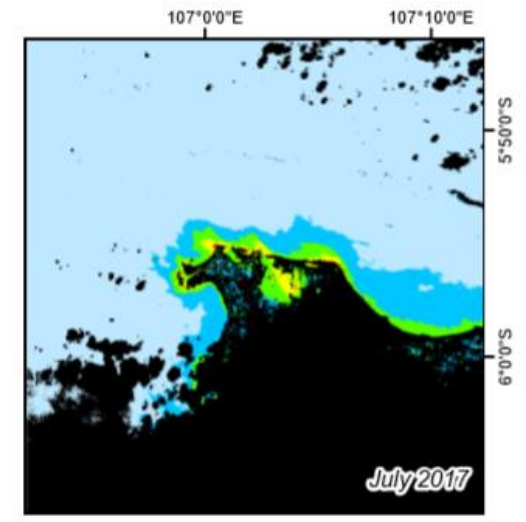

(c)

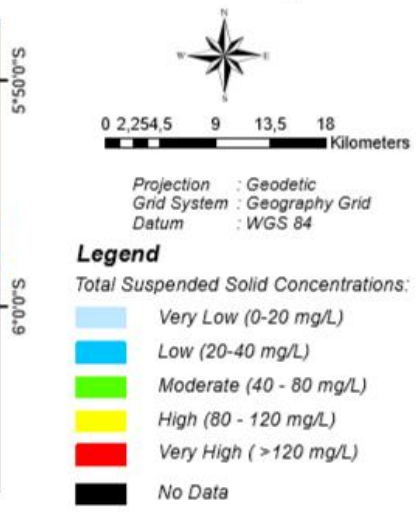

Total Suspended Solid Concentrations:

Very Low (0-20 mg/L)

Low (20-40 mg/

Moderate $(40-80 \mathrm{mg} / \mathrm{L})$

No Data

Figure 3. Distribution map of TSS concentration: (a) August 2015; (b) August 2016; (c) July 2017; (d) July 2018; and (e) August 2019.

Table 3. TSS concentrations ( $m g$ / L) in 2015-2019.

\begin{tabular}{cccccc}
\hline \multirow{2}{*}{ Points } & \multicolumn{5}{c}{ Years } \\
\cline { 2 - 6 } & 2015 & 2016 & 2017 & 2018 & 2019 \\
\hline 1 & 103.9 & Cloud & 75.8 & 68.4 & 70.9 \\
2 & 15.3 & 24.8 & 12.7 & 14.5 & 12.9 \\
3 & 13.7 & 22.1 & 12.3 & 13.3 & 12.5 \\
5 & 17.0 & 14.9 & Cloud & Cloud & 15.7 \\
6 & 19.2 & 14.9 & Cloud & 16.9 & 18.6 \\
7 & 22.2 & 14.7 & 15.5 & 14.1 & 17.4 \\
8 & 20.4 & 15.1 & Cloud & 13.4 & 16.1 \\
9 & 18.7 & 21.9 & 12.8 & 12.6 & 12.2 \\
10 & 13.7 & 16.8 & 12.9 & 11.5 & 11.7 \\
11 & 40.7 & 22.5 & 14.7 & 15.9 & 19.7 \\
12 & 70.4 & 28.2 & 20.0 & 22.2 & 25.3 \\
13 & 122.0 & 36.9 & 26.4 & 35.1 & 58.2 \\
14 & Cloud & 93.4 & Cloud & 110.2 & 155.6 \\
\hline
\end{tabular}

metode yang berbeda, yaitu metode empiris analitik (Budhiman et al., 2004). Terlihat (Adawiah et al., 2018) dan metode semi- bahwa konsentrasi MPT antara model 
empiris dan semi-analitik sangat berbeda. Model empiris cenderung menghasilkan nilai MPT yang sangat tinggi. Penelitian Camiolo et al. (2019) juga menunjukkan bahwa estimasi MPT dengan model empiris akan menghasilkan nilai yang jauh lebih besar daripada in situ. Padahal pembuatan model tersebut mengambil sampel perairan Bekasi. Berbeda dengan model semi-analitik yang dibangun pada lokasi berbeda, namun memiliki akurasi yang lebih tinggi. Model ini telah digunakan sebagai rujukan dalam penelitian yang lain, Hariyanto et al. (2017) menghasilkan bahwa metode ini memiliki nilai $\mathrm{R}^{2}$ yang sangat tinggi mencapai 0,982 dan Indeswari et al. (2018) juga menyatakan bahwa metode ini menghasilkan eror terkecil. Hal ini bisa terjadi karena perbedaan waktu ketika pengambilan data citra dengan data in situ. Selain itu, kondisi perairan yang bersifat dinamis dapat memengaruhi hasil tersebut secara signifikan. Selain waktu pengambilan data citra, juga terdapat faktor lain. Model Adawiah dibangun dengan model empiris. Model ini dibangun berdasarkan hubungan empiris antara sifat optik dan konsentrasi MPT di lapangan. Hubungan empiris memiliki sifat spesifik terhadap geografis, sehingga tidak dapat diterapkan di daerah lain (Kong et al., 2015). Penelitian ini pula menunjukkan bahwa model empiris juga spesifik terhadap waktu meskipun dilakukan pada lokasi yang sama. Hal ini memperlihatkan bahwa untuk dapat membangun model empiris yang baik, harus dilakukan pengambilan sampel pada kondisi perairan yang berbeda dari waktu ke waktu, sehingga kisaran konsentrasi yang ada pada kondisi waktu yang berbeda dapat diidentifikasi pada model empiris tersebut. Sedangkan model Budhiman dibangun dengan model semianalitik, model ini menggunakan hubungan antara IOP air laut dengan konsentrasi MPT. Kong et al. (2015) mengatakan bahwa model semi-analitik memiliki presisi inversi dan universalitas yang lebih tinggi daripada model empiris. Hal ini juga terlihat pada hasil penelitian yang menunjukkan bahwa nilai MPT yang dihasilkan dengan semianalitik memiliki korelasi yang lebih baik daripada dengan model empiris. Bernardo et al. (2019) juga menggunakan model semianalitik untuk mengestimasi MPT di perairan darat dan mendapatkan eror lebih rendah, yaitu $30 \%$.

Kedua model ini menunjukkan bahwa area di dekat-pantai didominasi dengan warna merah, yang berarti MPT yang terkandung sangat tinggi. Hal ini bisa terjadi, mengingat pada area tersebut banyak aktivitas industri, kegiatan pembudidayaan ikan, dan banyaknya muara sungai besar seperti Sungai Citarum, Muara Gembong, dan Muara Cikeas.

Pengujian validasi dilakukan pada langkah selanjutnya. Uji validasi ini dilakukan untuk mengetahui sejauh mana kemiripan/ kesamaan antara hasil pengolahan citra dengan hasil in situ. Uji validasi menggunakan citra Landsat 8 yang diakuisisi 1-30 Agustus 2019, sedangkan untuk pengambilan data in situ dilakukan pada 23-25 Agustus 2019. Data citra merupakan data yang telah dimosaik di GEE. Hasil uji validasi terlihat pada Table 2. Data in situ yang digunakan merupakan hasil pengambilan sampel secara langsung di 14 titik. Koefisien determinasi digunakan pada uji statistika untuk mengetahui hubungan antara hasil analisis citra dengan data di lapangan. Koefisien korelasi digunakan untuk mengetahui besarnya hubungan antara dua variabel atau lebih. Uji validasi dengan NMAE bertujuan untuk mengetahui metode yang digunakan sesuai atau tidak, dengan toleransi NMAE dengan nilai $\leq 30 \%$. NMAE sebagian besar digunakan untuk mengevaluasi keakuratan prediksi dan estimasi tren (Dolara et al., 2018). Nilai RMSE merupakan standar deviasi residual atau kesalahan prediksi. RMSE memberikan informasi mengenai besaran kesalahan nilai konsentrasi antara nilai prediksi dan nilai sebenarnya pada unit konsentrasi yang sama (Dolara et al., 2018). Nilai $\mathrm{R}^{2}$ dan koefisien korelasi pada kedua model sangat kecil. 
Namun nilai NMAE pada model semianalitik lebih mendekati syarat NMAE. Penelitian Indeswari et al. (2018) menyatakan bahwa koefisien korelasi yang tinggi belum tentu bahwa model yang digunakan sesuai untuk perairan tersebut dengan melihat nilai NMAE. Nilai NMAE yang berada dibawah $30 \%$ berarti memenuhi syarat digunakan untuk mengekstrak data kualitas air dari data pengindraan jauh (Sholihah et al., 2016). Nilai RMSE yang dihasilkan juga ternyata sangat besar untuk model empiris yaitu, sebesar 58.577,2, sedangkan model semi-analitik didapatkan sebesar 51.4. Hal ini tentu memperlihatkan bahwa model semi-analitik lebih sesuai untuk analisis sebaran MPT di perairan Bekasi.

Analisis berikutnya dilakukan secara time series untuk mengetahui kandungan MPT di perairan Bekasi selama 5 tahun terakhir. Pemilihan waktu ini berdasarkan musim. Bulan Juli dan Agustus sebagai musim kemarau. Data citra yang digunakan merupakan data yang terdapat dalam 1 bulan. Hal ini dimaksudkan untuk meminimalisir keberadaan tidak tersedianya data karena tertutup awan.

Peta persebaran MPT dapat dilihat pada Figure 4. Berdasarkan nilai konsentrasi in situ yang didapat (36-122 mg/L) dan untuk mempermudah perbandingan sebaran MPT antara tanggal perekaman satelit yang berbeda, maka dibuat pembagian rentang nilai konsentrasi dibagi menjadi 6 yakni Sangat Rendah (0-20 mg/L), Rendah (20-40 $\mathrm{mg} / \mathrm{L}$ ), Sedang (40-80 mg/L), Tinggi (80-120 $\mathrm{mg} / \mathrm{L})$, Sangat Tinggi (>120 mg/L), dan Tidak Ada Data. Kelas Tidak Ada Data mengindikasikan daratan dan juga awan. Terlihat bahwa pada tiap tahunnya, persebaran MPT berbeda-beda. Daerah pesisir memiliki nilai MPT yang sangat tinggi. Hal ini dikarenakan pada daerah tersebut terdapat banyak tambak. Penelitian (Mustofa et al., 2017) mengatakan bahwa limbah dari tambak sangat memengaruhi kualitas air. Keberadaan tambak memberikan pengaruh pada kandungan MPT yang tinggi karena menghasilkan limbah. Limbah budi daya juga merupakan sumber pencemaran. Bekasi merupakan salah satu daerah yang memiliki kegiatan tambak cukup tinggi. Produksi pada tiap tahunnya meningkat. Pada tahun 2017 produksi dari tambak sebesar 2.113,55 ton (Badan Pusat Statistik Karawang, 2018). Hal ini mengindikasikan bahwa daerah pesisir juga akan menghasilkan MPT yang tinggi. Keberadaan muara sungai memberikan kontribusi pada kandungan MPT yang tinggi. Semakin mendekati laut lepas, konsentrasi MPT akan semakin kecil, hal tersebut tidak terlepas dari pengaruh kecepatan arus sungai dan ukuran dari partikel MPT yang ada. Semakin tinggi arus sungai, maka proses pengadukan kolom air semakin tinggi (tergantung juga dari kedalaman sungai), serta proses sedimentasi dari padatan tersuspensi akan semakin luas. Umumnya MPT memiliki konsentrasi tertinggi di sekitar daratan dan muara sungai, dan akan semakin berkurang di laut lepas (Parwati, 2014).

Analisis selanjutnya dengan melihat konsentrasi pada masing-masing titik (Table 3). Setiap tahunnya, persebaran MPT cenderung mengalami kenaikan. Titik 1, 12, dan 13 cenderung menghasilkan nilai MPT yang tinggi. Hal ini dikarenakan posisi titik 1 berada pada muara Sungai Citarum. Penelitian lain juga menjelaskan bahwa kandungan MPT pada muara sungai sangat tinggi (Arifelia et al., 2017; dan Purba et al., 2018). Nilai data yang digunakan masih dalam surface reflectance. Nilai ini masih mengandung eror dari nilai yang dipantulkan oleh permukaan air. Perlu dilakukan penelitian lebih lanjut terkait data yang digunakan, yaitu berupa nilai water leaving radiance untuk meminimalkan eror.

\section{KESIMPULAN}

Pemantauan sebaran MPT di perairan Bekasi dari data satelit pengindraan jauh, dilakukan menggunakan model empiris (2018) dan semi-analitik (2004). Model 
empiris menghasilkan konsentrasi MPT yang sangat tinggi daripada model semi-analitik. Hasil uji validasi dengan data in situ menunjukkan nilai NMAE model semianalitik lebih mendekati syarat dan nilai RMSE yang lebih kecil daripada model empiris yang berarti bahwa model semianalitik lebih sesuai dalam analisis selanjutnya. Hasil analisis juga menunjukkan bahwa model empiris tidak hanya tergantung pada lokasi penyusunan model, tetapi juga tergantung pada waktu penggunaan model empiris. Walaupun model empiris yang digunakan adalah model empiris yang dibangun pada daerah yang sama, namun akan memberikan eror yang tinggi, karena model empiris lebih mempertimbangkan nilai in situ sebagai masukan dalam pengembangan modelnya, apabila rentang nilai saat pembuatan model empiris belum mewakili rentang nilai konsentrasi yang sebenarnya ada di lokasi pengamatan, maka model empiris akan memberikan eror yang tinggi.

\section{UCAPAN TERIMA KASIH}

Ucapan terima kasih ditujukan kepada Pusat Pemanfaatan Pengindraan Jauh LAPAN. Riset ini merupakan bagian dari kegiatan INSINAS Kualitas Perairan pada Pusat Pemanfaatan Pengindraan Jauh LAPAN yang dibiayai Ristekdikti dengan SK Keputusan Direktorat Jenderal Penguatan Riset dan Pengembangan Nomor 4/E/KPT/ 2019 dan Kontrak Pelaksanaan Insentif Penelitian Program Insentif Riset Sistem Inovasi Nasional Gelombang I Tahun Anggaran 2019 Nomor 14/INS-1/PPK/E4/ 2019.

\section{DAFTAR PUSTAKA}

Adawiah, S.W., R. Faristyawan, N. Suwargana, E. Parwati, \& M. Arief. 2018. Pengembangan model pemanfaatan penginderaan jauh untuk ekstraksi informasi kualitas perairan. Laporan Kegiatan Litbangyasa
(Tidak Dipublikasikan). Lembaga Penerbangan dan Antariksa Nasional. Jakarta. 59 p.

Arief, M., S.W. Adawiah, M. Hartuti, \& E. Parwati. 2017. Algoritma dua dimensi untuk estimasi muatan padatan tersuspensi menggunakan data satelit landsat-8, studi kasus: Teluk Lampung. J. Penginderaan Jauh dan Pengolahan Data Citra Digital, 13(2): 109-120.

https://doi.org/10.30536/j.pjpdcd.201 6.v13.a2517

Arifelia, D., G. Dianysah, \& H. Surbakti. 2017. Analisis kondisi perairan ditinjau dari konsentrasi Total Suspended Solid (TSS) dan sebaran klorofil-a di muara Sungai Lumpur, Sumatera Selatan. J. MasparilMarine Science Research, 9(2): 95104.

https://doi.org/10.36706/maspari.v9i2 .4475

Badan Pusat Statistik Karawang. 2018. Kabupaten Karawang dalam angka. Badan Pusat Statistik Kabupaten Karawang. Karawang. 432 p.

Baird, R.B., A.D. Eaton, \& E.W. Rice. 2017. Standard methods for the examination of water and wastewater. American Public Health Association. Wasington DC. 1546 p.

Bernardo, N., A. Carmo, \& E. Park. 2019. Retrieval of suspended particulate matter in inland waters with widely differing optical properties using a semi-analytical scheme. Remote Sensing, 11(19): 1-22. https://doi.org/10.3390/rs11192283

Budhiman, S., T.W. Hobma, \& Z. Vekerdy. 2004. Remote sensing for mapping TSM concentration in Mahakam Delta: an analytical approach. In: Liu et al. (eds.). Proceeding of The Thirteen OMISAR Workshop on Validation and Application of Satellite Data for Marine Resources 
Conservation 2004, Bali, October 5-9 2004. 1-15 pp.

Camiolo, M.D., E. Cozzolino, A.I. Dogliotti, C.G. Simionato, \& C.A. Lasta. 2019. An empirical remote sensing algorithm for retrieving total suspended matter in a large estuarine region. Scientia Marina, 83(1): 5360.

https://doi.org/10.3989/scimar.04847. $22 \mathrm{~A}$

Dolara, A., F. Grimaccia, S. Leva, M. Mussetta, \& E. Ogliari. 2018. Comparison of training approaches for photovoltaic forecasts by means of machine learning. Applied Sciences (Switzerland), 8(2): 1-16. https://doi.org/10.3390/app8020228

Dorji, P., P. Fearns, \& M. Broomhall. 2016. A semi-analytic model for estimating total suspended sediment concentration in turbid coastal waters of northern Western Australia using MODIS-Aqua $250 \mathrm{~m}$ data. Remote Sensing, 8(7): 33-38. https://doi.org/10.3390/rs8070556

Hariyanto, T., T.C. Krisna, Khomsin, C.B. Pribadi, \& N. Anwar. 2017. Development of total suspended sediment model using Landsat-8 OLI and in-situ data at the Surabaya Coast, East Java, Indonesia. Indonesian J. of Geography, 49(1): 73-79.

http://doi.org/10.22146/ijg.12010

Indeswari, L., T. Hariyanto, \& P.C. Bekti. 2018. Pemetaan sebaran Total Suspended Solid (TSS) menggunakan citra landsat multitemporal dan data in situ (studi kasus: perairan muara Sungai Porong, Sidoarjo). J. Teknik ITS, 7(1): 2337-3520. https://doi.org/10.12962/j23373539.v $7 \mathrm{i} 1.28698$

Kong, J.L., X.M. Sun, D.W. Wong, Y. Chen, J. Yang, Y. Yan, \& L.X. Wang. 2015. A semi-analytical model for remote sensing retrieval of suspended sediment concentration in the Gulf of Bohai, China. Remote Sensing, 7(5): 5373-5397. https://doi.org/10.3390/rs70505373

Ligi, M., T. Kutser, K. Kallio, J. Attila, S. Koponen, B. Paavel, T. Soomets, \& A. Reinart. 2017. Testing the performance of empirical remote sensing algorithms in the Baltic Sea waters with modelled and in situ reflectance data. Oceanologia, 59(1): 57-68.

https://doi.org/10.1016/j.oceano.2016. 08.002

Menteri Lingkungan Hidup. 2004. Keputusan Menteri Negara Lingkungan Hidup Nomor 51 Tahun 2004. Kementrian Lingkungan Hidup. Jakarta. 1498 p.

Mustofa, A., U. Islam, \& N. Ulama. 2017. Kandungan total zat padat tersuspensi dari outlet tambak. J. DISPROTEK, 8(1): 34-45.

https://doi.org/10.34001/jdpt.v8i1.484

Parwati, E. 2014. Analisis dinamika fluktuasi tss (total suspended solid) sepanjang DAS-muara-laut di perairan Berau Kalimantan. Dalam: Hasyim et al. (eds.). Prosiding Seminar Nasional Penginderaan Jauh 2014, IPB International Convention Center, Bogor, 21 April 2014. 662-670 pp. https://doi.org/10.12962/j23373539.v $7 \mathrm{i} 1.28698$

Parwati, E. \& A.D. Purwanto. 2017. Time series analysis of total suspended solid (TSS) using landsat data in Berau Coastal Area, Indonesia. International J. of Remote Sensing and Earth Sciences (IJReSES), 14(1): 61-70.

https://doi.org/10.30536/j.ijreses.2017 .v14.a2676

Purba, R.H., Mubarak, \& M. Galib. 2018. Sebaran Total Suspended Solid (TSS) di kawasan muara Sungai Kampar Kabupaten Pelalawan Provinsi Riau. J. Perikanan dan Kelautan, 23(1): 21-30. 
Sholihah, I., L.M. Jaelani, \& T. Salam. 2016. Analisis sebaran padatan tersuspensi dan transparansi perairan menggunakan landsat 8. J. Teknik ITS, 5(2): 5-8. https://doi.org/10.12962/j23373539.v 5i2.17175

Received : 9 December 2019

Reviewed : 11 April 2020

Accepted : 13 July 2020 
